Article

\title{
Reimagining Digital Literacies from a Feminist Perspective in a Postcolonial Context
}

\author{
Maha Bali \\ Center for Learning and Teaching, The American University in Cairo, New Cairo 11835, Egypt; E-Mail: bali@aucegypt.edu
}

Submitted: 18 December 2018 | Accepted: 10 March 2019 | Published: 11 June 2019

\begin{abstract}
Although there are many intersecting but also conflicting definitions and understandings of digital literacy, for the most part, the majority allude to critical thinking in some form or another. This article attempts to imagine a conception of digital literacy and practice of teaching digital literacy that considers a different approach to being critical while using digital technology to consume, produce and communicate. The approach builds on the feminist work of Belenky, Clinchy, Goldberger and Tarule's (1986) Women's Ways of Knowing. The author will also share from her own teaching experience as a postcolonial scholar teaching Egyptian students at an American liberal arts university.
\end{abstract}

\section{Keywords}

critical thinking; digital literacies; digital platforms; empathy; fake news; feminist critical thinking

\section{Issue}

This article is part of the issue "Critical Perspectives on Digital Literacies: Creating a Path Forward", edited by Hiller A. Spires (North Carolina State University, USA).

(C) 2019 by the author; licensee Cogitatio (Lisbon, Portugal). This article is licensed under a Creative Commons Attribution 4.0 International License (CC BY).

\section{Introduction: Beyond Digital Literacies as Technical Skills}

Despite different definitions and understandings of digital literacy, most frameworks used in the educational technology field consider it multi-dimensional, and almost all consider information literacy a critical component of it (Alexander, Adams Becker, Cummins, \& Hall Giesinger, 2017); one can consider information, media and digital literacy as belonging to a family of literacies, but with different foci (Hobbs, 2010). However, the landscape of digital literacy has evolved beyond the traditional understanding of information literacy because of the proliferation of social media as a new source of dissemination of information, influencing which information we see and how, and our ability to widely share information generated by users (Alexander et al., 2017; El Rayess, Chebl, Mhanna, \& Hage, 2018), information with no clear accountability to establish credibility. A key difference between critical media literacy and critical digital literacy is that, in social media, "meaning-making occurs through diverse sources connected in multiple ways or networks. This draws attention to the kind of agency and "distributed expertise" (2010, p. 21) that may be generated through these "dynamic systems" (Hartley, 2010, p. 21, as cited in Burnett \& Merchant, 2011, p. 49) and therefore approaches to critical media literacy that emphasize macro power structures need to be newly imagined and nuanced in the digital literacy sphere.

Digital literacy therefore intersects with both information and media literacies, but also involves components unique to the digital, such as understanding of how social media collects data and how search algorithms work, concerns about privacy and surveillance online, and understanding and experience of how multimodal content can be created and shared. An understanding of the interplay of all of these is needed, for example, when examining the credibility of fake news.

In this article, I argue that digital literacies should not be taught as a technical skill, but should be seen as a part of cultivating critical citizenship (Hobbs, 2010; Pangrazio, 2016). As such, knowing how to assess the credibility of information, knowing how platforms collect our data, and knowing how algorithms control what we see online, 
should not be taught as instrumental decontextualized skills and knowledge. We need to emphasize the ways in which misinformation, privacy violation and oppressive algorithms work together to create systems that distort our views of the world, and thus our political and civic action in the world, and we need to work towards raising consciousness of these power structures (Jenkins \& Joll, 2014; Pangrazio, 2016), and nurturing agency to resist them using participatory approaches influenced by the work of Paulo Freire and John Dewey (Burnett \& Merchant, 2011; Jenkins \& Joll, 2014; Pangrazio, 2016). This involves building awareness of how bias towards different others, lack of awareness of context, and blindness to inequities creates an environment where digital platforms can expose us to more and more ideologically extreme content and manipulate our worldview (Noble, 2018) if we are not careful as communities and not just as individuals (Hobbs, 2010). These ends often promote injustice towards marginal groups such as immigrant populations, for example, influencing how people treat them and vote politically on issues related to them. Learners also need to know the roles they can play in exacerbating such problems when they share non-credible, partiallyfalsified or biased information to audiences on social media, even when taken lightly. They need to collectively develop attitudes, habits and mechanisms to resist, and therefore teaching digital literacies should include collective learning outcomes as Ito and her colleagues propose (Ito et al., 2013), recognize how social media makes "new forms of sociality possible" (Rheingold, 2012, p. 251) and approach critical digital literacy as a "social skill" (Jenkins \& Joll, 2014). While much literature on critical media literacy touches upon these attitudes (to be discussed in Section 2), the majority of mainstream digital literacy literature used by educational technologists (e.g., the report comparing various models by Alexander et al., 2017) does not build on this feminist-inspired work, and the work of critical digital literacy that does build on critical media literacy literature does not, for the most part, focus on what is distinctly digital such as the specifics I outlined above (Pangrazio, 2016).

Rather than simply aiming to help students follow a set of steps to detect fake news, as an antagonistic, individual endeavor that builds a disposition of skepticism, we need to build students' awareness of how their own contextual knowledge and biases lead them to believe or disbelieve in the first place, an awareness of how and why information is created and shared online, and how their understanding and empathy towards the "other" can influence their disposition to believe and share negative things about those with whom they disagree, for example. Knowing how to assess the credibility of a source is useless unless the person develops a sensitivity and disposition to question what reasonably warrants questioning. And it is insufficient for individuals to do this, if collectively we do not find ways to do this together and for each other, because the influence of finding something widely shared tends to create an illusion of believability.
A larger awareness of systemic inequalities and social injustice is needed to raise consciousness about how digital platforms can reproduce these inequalities and further distort our views (Hobbs, 2010; Ito et al., 2013; Noble, 2018). And as we learn about these, we should not simply promote individualistic reactions such as "leave Facebook" but rather collective action such as gathering to advocate for government and platforms to modify the laws and policies related to data (as Europe has been doing).

I teach a course I designed a few years ago entitled "Digital identities and digital literacies in an intercultural context" at the American University in Cairo in Egypt, and the majority of my students are Egyptian (a few are cultural hybrids). As a postcolonial scholar teaching postcolonial students at a hybrid American/Egyptian institution, my approach to teaching digital literacies foregrounds reflections on identity and hybridity, a questioning of our own and others' biases while promoting empathy for "the other", and an exploration of equity issues in real life and in the digital realm, before delving into digital literacies and topics such as fake news, privacy, data and algorithms. And all of these topics are tackled in a contextual manner. When I say "postcolonial" here, I am referring to a country and individuals "that have histories of colonial oppression and anti-colonial, post-colonial and de-colonizing struggles...[one among many] regions of the world that continue to live with the consequences of colonial legacy in culture, subjectivity and knowledge" (Takayama, Heimans, Amazan, \& Vegneskumar, 2016, p. 5). It is also important to recognize the context of Egypt and Egyptians after the 2011 revolution and the ensuing political conflicts, and how this influences young people's approaches to citizenship and digital citizenship, given the important role of social media in the 2011 revolution (Bali et al., 2019). The context of the American University in Cairo as a hybrid institution, and students' own educational backgrounds (which often entail some form of European education in their schooling) tends to reinforce neocolonialism and its impact on students' culture, in terms of their exposure to Western academic sources and approaches and Western (particularly Anglo and American) popular media; the digital context only reinforces this as many of the technologies are designed in the West and enhance exposure to Western content and approaches to knowledge. Postcolonialism as a field of inquiry focuses on "the aftermath of European colonialism, including issues of representation, otherness, diaspora, hybridity and voice" (Asgharzadeh, 2008, p. 338) and emphasizes the "contemporary ramifications" of colonial history on "borders, multiple identities, interdependent economies, and hybrid cultures" (p. 338). These are all realities in my life and my students' lives, and I cannot imagine approaching digital literacies without addressing these issues.

Studying and teaching digital literacy can be seen as a neutral, rational undertaking, meant to develop workplace skills, but as shown in Section 2, it is not. The im- 
perialist dimension of technology in general also needs to be recognized: "Coloniality can be understood as a system that defines the organization and dissemination of epistemic, material, and aesthetic resources in ways that reproduce modernity's imperial project", which involves aspects such as seamless progress, democracy, and universalism (Andreotti, Stein, Ahenakew, \& Hunt, 2015, p. 23), dimensions often associated with technology and discourses surrounding it. Therefore, teaching digital literacy in critical ways must entail questioning the modernist discourses we are exposed to on a daily basis.

I would argue that we might do well to consider more feminist approaches to criticality, that center context, creativity, intuition, empathy and a social justice orientation, and apply them to our teaching of digital literacy, particularly in the Egyptian context where this is needed for constructive critical citizenship in a country where schooling does not promote critical thinking (Bali et al., 2019) nor does it provide any introduction to information, media or digital literacy beyond some basic technological skills. The next section explains the theoretical underpinnings of my approach.

\section{Alternative Conceptions of Criticality}

\subsection{Parallels with Alternative Understandings of Critical Thinking}

Teaching critical digital literacies involves encouraging students to be critical while consuming, producing and communicating using digital technologies, and to develop judgment of which tools to use, when to use them, and to reflect on their purpose for using them, and how this influences their choices.

The ideas behind the approach to digital literacies I use is inspired by the multiple conflicting understandings of "critical thinking" (CT; Bali, 2013) and how cultured and gendered they are. Broadly speaking, "first wave" CT (Walters, 1994) draws on the dominant North American CT movement, referring to CT as reasoning, logic, skepticism and argumentation (see Facione's, 1990, Expert Consensus), and this is most commonly used by universities (Brodin, 2007). This approach for the most part treats CT as a technical skill. On the other hand, "second wave" CT (Walters, 1994) is inspired by Marxist and feminist perspectives and often involves social justice and critical action, and valuing things like intuition and creativity (key figures include Brookfield, 1987; Benesch, 1999, 2001; Freire 1970/1993; Barnett, 1997; Belenky, Clinchy, Goldberger, \& Tarule, 1986). An important distinction between first and second CT is that first wave is often individualistic and cognitive, whereas second wave emphasizes collective and communal (Johnson \& Morris, 2010) action with reflection (Barnett, Giroux). First wave CT often leads to pedagogies that promote antagonistic debate and argument, which many women and minorities and some men find uncomfortable, and thus a hindrance to learning (Belenky et al., 1986).
For most faculty members at my institution, there is a lay understanding of what "critical thinking" means, which is not often influenced by feminist theory nor critical pedagogy (unless this is common within their academic field), and therefore, if and when they attempt to infuse information or digital literacies in their courses, they are unlikely to use a feminist or critical pedagogy approach.

In what follows, I first share the theoretical influences on my own thinking about approaching the teaching of critical thinking, given my background in studying CT and education, and my work experience as a faculty developer where educational technology is one of my areas of expertise; however, I later describe literature in the critical media literacy field which intersects with many of the values I mention, but which I only learned about after teaching the course several times. I hope to highlight that different understandings of what "criticality" entails influences all areas of teaching.

\subsection{Contextual Digital Literacy?}

A key debate within the CT movement relates to teaching CT as a generic technical skill in a separate course versus teaching it as subject-specific and via immersion (led by McPeck, 1990). This can be applied to teaching digital literacies as well. Consider specifically the case of investigating fake news. An individual is unlikely to investigate the credibility of something unless they have sufficient knowledge about the subject matter and context to make them sufficiently skeptical.

One of the main findings of Belenky et al. (1986), is that many women in particular and some men have a natural disposition and preference towards believing and understanding what they are exposed to first (what Elbow 1994 calls the "believing game") rather than what traditional approaches to CT expect, which is a more skeptical disposition (what Elbow 1994 calls "the doubting game"). If we consistently teach CT out of context and only emphasize skepticism, many students (particularly females) may follow our steps or rules within the classroom but not develop the habit to apply them outside the classroom because of their innate resistance to it. Belenky et al. (1986) call these women "connected knowers" versus traditional CT which promotes "separate knowing". Connected knowers learn more by trying to empathize and learn about the other (person or object) before doubting them. Their path to becoming critical thinkers differs from traditional CT and as they mature, they become what Belenky et al. call "constructive knowers" who are comfortable with the complexity of the world, with ambiguity and uncertainty, and are characterized by "the opening of the mind and the heart to embrace the world" (p. 141). They are able to connect their own experience with external knowledge, merging both rationality and empathy-whereas separate knowers mostly work on divorcing their own feelings and experience from their interaction with knowledge, where 
rationality completely suppresses emotion and empathy. Also among the findings of Belenky et al. is that teaching that does not show the processes of thinking of the teacher, or allow students to find their own path towards knowledge, can be intimidating for women who are at the connected knowing phase (a phase less mature than the more confident constructive knower). These women need affirmation of the value of their own experiences in constructing knowledge, versus external authorities and external rules to follow. It is also important to recognize the potential negative impact of "institutionalization of critique", where it risks young people treating critique as attitudes authority figures favor, or even correct and incorrect answers, "which are unlikely to hold any transformative power as they will weigh unfavourably against the situated meanings with which learners identify" (Burnett \& Merchant, 2011, p. 45).

These approaches seem more important for me in the postcolonial context of Egypt, since students are taught early on to value Western knowledge over local, and academic knowledge over personal experience. One way to empower these students to have voice is to encourage them to build on local knowledge and personal experience as valid and important sources of learning. One can also support students in making connections between their own personal experiences and understanding broader ideologies and power structures (Pangrazio, 2016).

Interestingly, the vocabulary of connection has been used in the digital context of the "connected learning" model (see Ito et al., 2013) which "advocates for broadened access to learning that is socially embedded, interest-driven, and oriented toward educational, economic, or political opportunity" and emphasizes the pursuit of "a personal interest or passion with the support of friends and caring adults" involving "individual interest as well as social support to overcome adversity and provide recognition" (Ito et al., 2013, p. 4). Connected learning is also explicitly against instrumental and competitive approaches to learning, and instead is centered "on equity, full participation and collective contribution" (Ito et al., 2013, p. 33).

When we teach digital literacy in context, we have opportunities to highlight for students how their own background knowledge about a topic influences their intuitive response to whether a source is credible or deserves further scrutiny. Rather than teaching students how to doubt a source as a first step, we are affirming their own background knowledge about a topic, and helping them build on and explore their own intuition, in order to help them reach a conclusion. This gives students the opportunity to consider what they believe before they delve into the trickier portion of doubt, and hopes to enable them to continue doing this outside the classroom as it builds on what they would naturally do as a starting point.

Thayer-Bacon (1998) stresses the contextuality of CT, something which contradicts the CT movement's more abstract notions of CT. Thayer-Bacon (1998) uses the term "constructive thinking", building upon Women's Ways of Knowing, and suggests a "dialectical relationship between social beings and ideas that is dynamic, flexible, and reciprocal", while also "addressing cultural influences and political power in theories about thinking" (p. 143). Therefore, when we teach about assessing credibility of a source of news, we need to also explore with students issues of confirmation bias and how we are more likely to believe information that agrees with what we already believe, how exposure to multiple perspectives and sources of news broadens our baseline knowledge of different worldviews, and how social media platforms, algorithms and external power structures of knowledge distort what we become exposed to. Teaching in this way encourages students to assume agency to overcome the ways in which these technologies can narrow their view of the world.

\subsection{A Feminist Approach to Teaching Digital Literacies}

If I were to describe my approach to applying Belenky et al.'s (1986) work to the teaching of digital literacies, I would summarize it as follows:

1. Exploration and discussions of identities, empathy, bias and equity before delving into specifics of digital literacies. This enables students to selfreflect and question how their own and others' biases, feelings and knowledge influence how they approach a matter-and also to possibly understand why certain people choose to undertake particular actions. For some insight into my open curriculum, please see Equity Unbound website which I co-developed (http://unboundeq. creativitycourse.org). Equity Unbound is an equityfocused, open, connected, intercultural learning curriculum, influenced by the connected learning model which embodies "values of equity, social belonging, and participation" (Ito et al., 2013, p. 8).

2. Embrace digital literacies in a holistic manner that highlights the interplay between digital platforms, their collection of data, their algorithms, and what we know about how media can be manipulated, how news can be falsified and how false information can spread.

3. We explore context and what we already know, feel and believe about something before we investigate it. We build on existing knowledge and experience, and also bring forward awareness of our own biases and biases of others.

4. Being explicit about process in the classroom. Not every news item we investigate in class is one where I already have a conclusion. We go through the process of investigation individually then share with the group and explore nuances of "most likely true" or "false with a grain of truth" or "possibly true but biased" rather than simply real or fake. We also explore why someone might spread false 
information and our roles in spreading or preventing such fake information.

5. Being explicit about an overarching goal of striving towards social justice and better understanding in the world, rather than gaining a skill to argue better or detect lies. An understanding that there may be sinister underpinnings as part of larger systems of power in the world, but that we have agency as individuals and as a society to resist.

\subsection{Intersections with Feminist Approaches to Critical Media Literacy}

While I developed my own approach to teaching critical digital literacy from a feminist perspective, I later discovered literature in critical media literacy that also follows feminist approaches, and a number of approaches to critical digital literacies that are not often mentioned in reports on digital literacy frameworks such as Alexander et al. (2017). Much of the seminal work came before the advent of social media (e.g., Kellner \& Share, 2005; Luke, 1994; Luke, 2000, as cited in Pangrazio, 2016) but has much to offer that can be useful for digital literacy (Pangrazio, 2016).

For example, this quote from bell hooks (1996, p. 3, as cited in Kellner \& Share, 2005, p. 375) when the internet was still in its infancy can be applied to digital literacy: "While audiences are clearly not passive and are able to pick and choose, it is simultaneously true that there are certain 'received' messages that are rarely mediated by the will of the audience". It is important for teaching of digital literacy to unpack how algorithms and technological platforms have a role in this despite each individual's agency as a user of technology. In Egypt's postcolonial context, it is also important to recognize how much of this messaging comes from a different culture than their own, which attempts to dominate their thinking in subtle and explicit ways.

Luke (1994) proposes that teaching of critical media literacy begin with exploration of student identities (also emphasized by Burnett \& Merchant, 2011, in the more current context of social media) which is something I foreground in my course title and especially in the beginning of teaching my course. Luke also suggests the use of "open-ended and collaborative, not competitive, learning experiences" (p. 44), which is something I try to emphasize as inspired by the work of Belenky and her colleagues. She also emphasizes how feminist pedagogy should challenge hierarchy and student-teacher relationships and traditional forms of knowledge, and explore intersectionality of power and privilege, which also entails diverse content choices and teaching and assessment methods. These are things I do in my class by often not placing myself as the authoritative source of knowledge, and learning out loud with my students, as well as inviting them to contribute resources and alternative ways of addressing issues we discuss in class. This is particularly important in Egypt where questioning author- ity is strongly discouraged in schooling and in life in general (the January 2011 revolution notwithstanding, and, as suggested by Bali et al. (2019) not necessarily representing deep criticality). Luke also emphasizes the importance of encouraging students to not only question popular media, but also more academic sources teachers use-some of the examples I share in future sections will highlight how I attempted to do this in my teaching.

Addressing intersectionality is particularly relevant to my context because in many ways my students are privileged: they are studying at a private non-profit American institution in Egypt, arguably one of the better universities in Egypt and the region. The majority are from privileged backgrounds and have received international schooling. But in other ways they are marginalized, because of their Egyptian (versus Western) identity. Most of them are Muslim, the majority religion in their country, but one which is attacked in the Western media because of so-called Islamic terrorism. In many ways, they feel marginalized and misunderstood, even as they recognize their local privilege. Some of them are cultural hybrids due to parenting or birthplace, but almost all of them are culturally hybrid because of their Western education even if those who have lived in Egypt all their lives.

Kellner and Share (2005) emphasize the importance of integrating multicultural and social difference within media literacy studies and the ways critical media literacy as a field has been influenced by critical pedagogy and feminist theory. This intersects with my own course design that interweaves intercultural learning with digital identities and digital literacies from the get-go and is influenced by feminist pedagogy. Integrating these involves understanding and questioning the processes of knowledge construction and issues of equity and social justice in media representation and the ways they can reproduce marginalization of already marginalized groups (Kellner \& Share, 2005), and these are dimensions I address directly in my classes.

There are models of critical digital literacy influenced by critical media literacy, but there is a lack of engagement with the uniquely digital aspects of digital literacy (Pangrazio, 2016), such as the fact that "fluidity and instability, multiple meanings, readings and interpretations are a feature of digital environments and notions of positionality and ideology become much harder to pin down" (Burnett \& Merchant, 2011). There are two approaches to digital literacy that are often in opposition: "either critical consumption or creative production; and builds either the technical skills of design or the more general, theoretical skills of critique. Such binary opposition has fragmented critical digital literacy along theoretical lines" (Pangrazio, 2016, p. 168). Pangrazio therefore proposes an approach that merges both:

Unpacking and understanding how ideology is made affective and personal could therefore become a powerful method of critique in the digital context. In this way the individual is the axial point; however, 
their personal experiences might be a 'portal' through which to explore the deeper ideologies that structure the reality of the digital context. (Pangrazio, 2016, p. 168)

One approach would be to teach about social media critique by accounting "for the ways in which individuals' meaning-making practices help them to perform identities within relational networks and how these networks contribute (or not) to that sense of belonging" online (Burnett \& Merchant, 2011, p. 50).

Hobbs (2010) makes connections between media and digital literacies as involving social and ethical dimensions: “When people have digital and media literacy competencies, they recognize personal, corporate and political agendas and are empowered to speak out on behalf of the missing voices and omitted perspectives in our communities" (p. 17). These are goals I strive for my students to achieve in my course. In a country where social media was used to support a revolution in 2011, students need to think critically about how this happened but also be aware of the strengths and limitations of social media, and its potential for connecting with others and for being critical citizens, but also the risks of cyberbullying and corporate and state surveillance.

\section{In Practice: Culturally Contextual Teaching of Critical Digital Literacies}

In what follows, I share several examples of culturally contextual teaching of critical digital literacy from my own course. Throughout the course, I intentionally select content that comes from the global South whenever possible, and attempt to provide examples relevant to student lives. Students' public blogs from the course are aggregated over several semesters and can be found at http://diglit.creativitycourse.org. Quotes by students, unless otherwise specified, are from their blogs, which are listed in the reference section of this article.

\subsection{Trump/Mecca Video: Teaching about How Context Influences Our Skepticism}

It is important to encourage students to be aware of their own biases when they attempt to evaluate the credibility of online sources. To make them ask themselves, "what made me feel skeptical about this, and made me search to check its credibility" and "is there anything inside me that automatically biases me to believe or disbelieve something, and why" (confirmation bias). As such, it is important when teaching students to evaluate credibility that it is a spectrum, that some of the things we are evaluating are either mostly true, or have elements of truth, so students do not assume they should be equally skeptical of every single thing, or that everything is equally non-credible. Overemphasizing skepticism can result in students losing faith in the existence of any truth at all, and this is dangerous (Bali,
2018; El Rayess et al., 2018). It is also important to recognize how previous information and biases we have influence how we look at a new piece of information-and to remind students that they may already have such knowledge, and be able to bring it to new situations. These are not technical skills or steps you learn and follow, but more nuanced constructed knowledge that each student will have developed over time. Aside from teaching students' skills about detecting fake news, we need to also discuss with them questions of bias, and how confirmation bias may mean our ideologies influence what we choose to believe or disbelieve.

For example, in the first few weeks of teaching, before we ever discuss fake news, I show students a video on YouTube of Donald Trump in the White House being interviewed for an American news show. In the video, Trump points to a large picture up on the wall and calls it "a sea of love" and talks about how people have come from all over the country, maybe the world, and it's a "sea of love". The picture is one of the Kaaba in Mecca and Muslims performing the pilgrimage (Hajj). I have shown this video to adults and students in Egypt and outside Egypt. Outside of Egypt, if people do not know what the Kaaba is, or that it is a Muslim pilgrimage, they have a neutral reaction to it. They don't see any particular dissonance. However, people who know Islam and recognize what the image is, start to express surprise. Among those are two camps: one camp believes the video is real, but express skepticism over why Trump might be talking about Islam in such a positive way. Some suggest he is trying to impress Saudi Arabia, or that he does not understand what he is looking at. This perspective is based on an understanding of American politics and relations with Saudi Arabia, and on the knowledge that Trump in general does not speak positively about Islam. A few people suggest that perhaps Trump has changed his perspective, or has a balanced perspective on "good" Islam versus terrorist Islam. Others, particularly younger students, start wondering if the video is fake and immediately start searching for alternatives. Quite quickly, they realize that the picture in the video was switched from one of Trump's inauguration (that's the "Sea of love" of people traveling for his inauguration) to one of Mecca. Three important things we discuss after we do this exercise are: first of all, you can question the authority of the professor; just because the professor is showing something in class, does not necessarily mean you should believe it; and second, it is OK and acceptable to try to first imagine why something that seems so unbelievable might be true (i.e. it is not naive to assume the video might be true; it shows empathy and a willingness to understand a perspective different from what your biases expect you to see); and the third thing is to question the agenda of someone who creates such a video. I don't know who created the video or why, but we discuss whether it was meant as a joke, or to improve Trump's image among Muslims, or something else, and whether it has potential to cause damage. We also discuss the impact of sharing 
such videos and memes, and what it means when they go viral, and each of our own roles in spreading material on social media when we are unsure of its credibility. Importantly, students learn that they already have some knowledge to bring to the classroom, that they are not learning about digital literacy in a vacuum, but that they can bring previous knowledge to the table and build upon it.

This resonates with Belenky et al.'s (1986) conception of the teacher as "midwife", coaching and supporting the student to bring their own knowledge to the fore, constructing new knowledge by building on what they already know and believe, rather than fostering skepticism and doubt as a priori valued attitudes. In the end, the students recognize that they are watching a falsified video. But they reach this knowledge by affirming what they already know to be true, and letting it lead them to this conclusion that the video must be fake because of other information they have which is true. Later in the course, students learn about Caulfield's (2017) "Four Moves and a Habit approach", but they are still free to explore other approaches to constructing their knowledge besides these steps. Caulfield's approach basically suggests that someone fact-checking a source should do this via a habit of checking their own emotions first when approaching this exercise, and applying these four moves: checking for previous work (that has fact-checked the source), going upstream to the source (i.e., finding the original source of the information used in the source you're looking at), reading laterally (finding out what others say about the reputation and credibility of the website, author, etc.) and circling back (i.e., start over again but using different search terms and pathways).

Blogging in hindsight about this activity, some students felt it was natural for them to be skeptical of the video immediately, because they "knew" Trump hates Muslims. But one student, Nermeen, demonstrated the Women's Ways of Knowing thought process:

If I was skeptical for a second I could have definitely known that it is fake but actually it didn't even cross my mind that it is fake because I though[t] "Why would the professor show us something that is not real?" and this taught me a lesson that I should always be skeptical about the knowledge I get from anyone and anyplace and always make sure that it is REAL. (Nabil, 2018a)

Another student, Hana El-Sherbiny (2018), also talks about the authority of the professor:

When seeing the video, I didn't think twice and that was because of the credibility of my professor, I thought that she would never show us something fake and it was also a video with trump's voice so how could it be?

Of course, students eventually learned to be skeptical of what they saw-not just as a knee-jerk reaction, but based on knowledge they already had. The same student, Hana, talks about how later in the course studying how fake news is created (via some games we played on the topic) helped her understand how fake news comes about, and that helped her skepticism.

In one class, a student recommended we watch a video about the "NASA Girl" (for English coverage of this, see Egypt Independent, 2018), an AUC student who created a viral fake news campaign claiming she would work with NASA to create a barbecue party underneath rockets as they launched. This started off originally as a joke, but people believed her and she kept getting more extreme and it became more and more viral. This was an example from our local context, and watching this girl relay her story, and discussing students' reactions to it was eye-opening. Some students who knew this girl in person said they did not believe her because they knew what kind of person she was and that she was always joking; others talked about how at first they did not believe, but as she posted more things on social media, they started to believe it. Some of us were hearing about it for the first time. In discussing this, students were building on what we knew of NASA in general, what we knew of this girl in specific (for those who knew her) and we discussed how knowledge of how someone can edit an image and make a post viral would influence how much we believed something.

\subsection{Empathy and Equity First}

As part of the course, students participate in intercultural web-based video dialogue via a program called Soliya Connect several times in the semester. Soliya Connect is a cross-cultural web-based video dialogue program, where a group of students from all over the world meet for two-hour sessions outside of class time but with a trained facilitator, to discuss cross-cultural issues in semistructured dialogues (see www.soliya.net). This experience helps promote both digital literacies and intercultural learning, but can also have inherent power dynamics and inequities (Bali, 2014). But before we enter into this experience of dialoguing online with culturally different others, we learn a lot about bias, empathy and equity. We play some narrative choose-your-own-path games that are meant to nurture empathy, and students then create their own games to promote awareness and empathy for populations and causes they care about, and post them on their blogs for other students and anyone else to play and give feedback (these are often educators in my network and their students). Games have been identified as one of the pedagogical methods that can nurture critical digital literacy (Hobbs, 2010), and while a game played in a few minutes is no substitute for the lifelong pursuit of gaining empathy for others, it is a form of digital storytelling that can provide a spark for understanding different worldviews that other forms of storytelling may not achieve. For example, student voices in Bali et al. (2019) include the following: 
The Spent digital narrative made me feel really empathetic towards those living in a constant financial struggle as it highlighted extremely tough and heartbreaking decisions that these individuals would have to make. (Autoethnographic account by student Fatma, p. 164)

The narrative games that we played and designed made me experience feelings of conflict, and I struggled to make decisions, ethical ones too, as if I were the person going through this....I think this aspect of the course, as subtle as it might have been, changed my apathetic side.... learned to use my digital skills to raise awareness through all different media about social justice whether it was through blogging, designing a game, or even ranting on social media. (Autoethnographic account by student Fayrouz, pp. 164-165)

When we were asked to design our own digital narrative games...even though I have never experienced domestic abuse, when designing this game I really had to put myself in the shoes of those who are and have experienced domestic abuse. (Autoethnographic account by student Jana, p. 165)

Creating our digital narrative games had the greatest impact on me...we obviously had to do some research about our topics. I chose to speak about street-sweepers in Egypt, which taught me a lot about their horrible living and working conditions, essentially making me feel extreme empathy towards them and therefore long for social justice for them and everyone I learnt about through the different narrative games found online and made by my classmates. (Autoethnographic account by student Fadila, p. 165)

We also conduct several activities to heighten awareness of inequity. By doing so before the Soliya intercultural dialogue (which take place outside class time, and students do them at different times without the instructor present but with a trained facilitator), they are better able to understand their place in the intercultural setting, how to listen well but also note inequalities related to use of language, technical infrastructure, and who holds power to control these online conversations. Students become aware of how their own hybridity (as Western-educated Egyptians) facilitates their interaction online with Americans, Europeans and other Arab students. They also sometimes see their own roles as bridges to help facilitate those conversations and move them forward. This also feeds into how they approach more digital literacy focused topics such as fake news, privacy and algorithms.

In their final reflections, many students talked about how important it was for them to learn through digital games that promoted empathy towards refugees, people with limited income, and others, and to create their own, and generally to question bias and appreciate empathy. Examples of games created by students include games to promote awareness of illiteracy in Egypt, child marriage, gender issues, drug addiction, being under the influence of alcohol, domestic abuse, and single motherhood (see links to examples of student work here: https://diglit.creativitycourse.org/classresources/digital-narrative-games). As previously reported (Bali et al., 2019), the activity of creating these games in itself has a strong influence on students' development of empathy as they research the topics and attempt to retell the stories in a choose-your-own-path format, as well as other readings and videos promoting empathy. One particularly striking reflection came from a male student, Karim:

I had always thought that I had some kind of weak side in myself as I always felt empathy towards people that are put in bad life situations and experiences. I have learned that empathy is a feeling that more or less everyone felt when we heard about some other person that is passing [by] atrocious events. The difference is only that some people show empathy more than others. In our society, people tend to be raised with a set idea that women have more empathy than men. In this class I have learnt that this is simply a myth. The myth of the strong wreck-less man the cute puppy hearted woman. I have learned that this was absolutely not what was actually happening. (Habashi, 2018)

\subsection{Teaching about Privacy and Surveillance from Our Context}

Much of the discussion on privacy of data is familiar to our students, but the real dangers of privacy and surveillance are quite different in an Egyptian context than in an American or European context. Students are aware of how corporations mine their data (some more than others), but what is truly worrying for them is the way organizations and governments surveil their data for political purposes and with potentially high political risks such as imprisonment or worse. As such, I try to focus my teaching on this topic on the work of Zeynep Tufecki, a Turkish scholar whose context is familiar to our students, and who makes connections between the 2011 Egyptian revolution in Tahrir Square and the more recent events of the election of Donald Trump (e.g., Tufecki, 2018). They therefore build a complex perspective on the social media that can be used for good, for communication, mobilization and liberation, but also for bad, for polarization, oppression and distortion.

\subsection{Questioning How We Understand Credibility}

Quite often, the criteria we use for assessing credibility can be imperial and colonizing. In my class, we discuss what it means to find information online, and which information is available online and in which languages and to whom it is accessible. One stark example of how the 
world online looks different to different populations is to look at Wikipedia. I discuss with students how Wikipedia is not actually a poor quality source of information as a "first stop" encyclopedia, and we discuss how information is edited on Wikipedia by anyone, but that there are editors and discussions in the background that attempt to ensure a minimum level of credibility. We also sometimes edit some Wikipedia pages during the course.

The example I give is the page on the October 1973 war and how the story is told on Wikipedia. The October 1973 war is seen in Egypt as a major victory, and there is a city and a bridge in Egypt named after 6th of October, which is a national holiday. The Arabic version of Wikipedia calls this event a victory for Egypt. The English version of Wikipedia uses almost the same facts as the Arabic version, but concludes that Israel eventually won that war. If someone were able to only read in one of those languages, they would only get one version of history. Now, granted, multiple versions of history have always existed and will always exist, but it is also important to note that my students come from a variety of disciplines, e.g. engineering, in which they do not normally discuss complexity and bias of historical knowledge with students, nor does the Egyptian education system promote this criticality at any point. But it is dangerous to assume that the supposedly democratic nature of the web, including Wikipedia and Google, means that anyone searching online will have access to a balanced perspective or all the possible views on a topic; on the contrary, there are dominant views that more easily visible via Wikipedia (English). We talk about Chimamanda Ngozi Adichie's (2009) "Danger of a Single Story" and who controls which story is told about a people (particularly postcolonial people), which stories we hear about ourselves online and how they influence how we see ourselves and others. Whose knowledge is privileged in the world and online?

We also talk about how Google's and YouTube's search algorithms and recommendations build on the popularity of searches of other people, what Google learns about our own searches, and often recommend more radical sites and videos to visit, in order to keep people online. We also learn about how these algorithms reproduce bias in the real world. These algorithms that were originally conceived as "value-neutral", in practice, never are.

\subsection{Limitations to This Approach in Practice}

There are several limitations to this approach in practice. One of the most difficult aspects of teaching this course is that the student population comes from different majors. I have students who are studying mass communication and therefore may have some understanding of digital literacy. At the same time, I have engineering and business students who probably have no such background. I also have political science and psychology students who may have familiarity with some of the messages of this course but not others. This course also draws students from computer science, who think they have more digital skills than everyone else but are unaware of their (frequent) lack of digital literacies. This means that there is no common foundation upon which to start the course, and outcomes for different students will differ (which I am comfortable with, as they have different goals coming into the course as well).

One major limitation is that approaches to teaching that decenter teacher authority run two major risks: first, that democratic classroom dialogue may end up creating space in the classroom for more dominant voices over quieter voices; this does indeed occur sometimes in class, where a particular student (sometimes, but not always, male) takes up large amounts of time during class discussions. It can also lead to views that do not align with social justice and equity to be heard, or for students to think "anything goes" as the teacher allows different viewpoints to be presented. This may result in some students listening but not changing their minds in any significant way if their original standpoints were strongly not social justice focused. A second risk this approach poses is that students who are more used to authority of the teacher end up confused: the teacher does not tell them about one correct method to applying digital literacy, but instead models a messy process of self-exploration, and in the end, they may not know for sure what worked and what did not, and how to transfer this to other contexts. We must consider that whereas Women's Ways of Knowing may work better for most female and minority students, it is still unfamiliar to most people in the class and may seem uncomfortable to most males and some students who have previously succeeded academically by using more traditional approaches to thinking critically.

It is also worth noting that nurturing these approaches for students may not help them in other academic endeavors where they are expected to demonstrate skepticism and perform antagonistic debate, for example.

\section{Considerations for Further Research}

This article, initially intended as a thought piece, did not follow a social science research methodology, unlike previously published collaborative autoethnography about the same course (Bali et al., 2019), but rather represents the instructor's own personal account, similar to an authoethnographic approach, and uses quotes from student public blogs as supporting evidence.

One possible direction for deepening this research in the future would be to analyze student reflective writing several times in the semester using particular prompts in order to glean where they stand on Belenky et al.'s framework, or to analyze it using Baxter Magolda's (2004) framework that sees parallels and pathways between Perry's model of intellectual development and Belenky et al.'s, so that we may see to what extent different students feel more comfortable thinking about digital lit- 
eracy with Perry's more masculine model or Belenky et al.'s model, and whether the course influences their approaches. This may also be achieved via class observations by an objective outsider, or via interviews as students think aloud about their approaches to digital literacy questions. This idea for future research is inspired by the paper by Fields (2001) applying Belenky et al.'s model to assessing women's epistemological development in student approaches to information literacy.

\section{Conclusions}

There are existing digital literacy frameworks that touch upon elements of what I mention here. The majority of models outlined and compared in Alexander et al.'s (2017) report on digital literacies do not take up critical or feminist conceptions of digital literacy in higher education. For example, Belshaw's approach includes a cultural and civic element to digital literacies, but "critical" here is not in the critical pedagogy sense; the Teaching Tolerance Digital Literacy Framework (2017) is one I recently discovered and includes elements of empathy and bias. Also, the well-known Information literacy framework, Association for College and Research Libraries ([ACRL], 2015), has a strong emphasis on understanding authority as constructed and contextual, and of working with process and conversation-but this framework centers mainly on information and not digital literacy per se. There are also critical feminist media literacy approaches as outlined by Luke (1994) and Kellner \& Share (2005) that build feminist approaches into teaching media literacy, emphasizing critique of power structures in media and also suggesting teaching practices that challenge student-teacher power relationships; however, I feel like these models intersect with but do not directly apply to the unique aspects of the digital (Pangrazio, 2016). While the work of Ito et al. (2013), Jenkins and Joll (2014) and Rheingold (2012) is uniquely digital and emphasizes sociality and networked aspects of the digital, focuses on equity, and alludes to Freire's work, they do not delve deeply into these issues from a feminist perspective. Pangrazio's (2016) model lays out a good theoretical foundation to conceive of a critical digital literacy, but to me, does not specify how to apply this in practice. I hope that my framing of digital literacy teaching practice as drawing its criticality from feminist conceptions of criticality provides a different route to teaching digital literacy that may both better support female and minority students, and more intentionally cultivate an empathetic and engaged citizenry in the postcolonial context of Egypt, but also in similar contexts beyond.

Reviewing my approach versus literature and results of applying it in practice:

1. An exploration and discussion of identities, empathy, bias and equity before delving into specifics of digital literacies. This approach intersects with values related to equity and participation mentioned by lto et al. (2013, p. 8) and emphasis on identities by Luke (1994) and Burnet and Merchant (2011). In practice, students come in with varying consciousness of equity and empathy, and some develop it better than others over the course. There was also one student who suggested we should speak instead about "othering" as a more systemic form of social bias, rather than bias and empathy on the more personal level. This is something I will consider in future semesters, and we showed a video this student recommended in class.

2. Embrace digital literacies in a holistic manner that highlights the interplay between digital platforms, their collection of data, their algorithms, and what we know about how media can be manipulated, how news can be falsified and how false information can spread. This takes the work of critical media literacy into the uniquely digital in the way described by Pangrazio (2016). Students often come in with an already skeptical mindset about how their privacy is violated by social media, but not necessarily practicing caution. They are often not completely surprised about how algorithms work, especially in terms of perpetuating existing power structures. The delicate balance here is between reaching a point of "social media is bad, let's disconnect completely", which many students start considering after watching TED Talks by Sherry Turkle, and a more constructive approach to becoming more critical consumers and producers of digital media, and becoming critical digital citizens (Hobbs, 2010).

3. We explore context and what we already know, feel and believe about something before we investigate it. We build on existing knowledge and experience, and also bring forward awareness of our own biases and biases of others. This has been working well for me in class, but some students have misunderstood "we are all biased" to mean "it is OK for me to be biased, and to act on it", rather than to mean "I need to recognize my biases and work towards consciously not acting on them and changing them".

4. Being explicit about process in the classroom. Not every news item we investigate in class is one where I already have a conclusion. We go through the process of investigation individually then share with the group and explore nuances of "most likely true" or "false with a grain of truth" or "possibly true but biased" rather than simple real or fake. This builds on the work of Belenky et al. (1986), and intersects with notions by others (Kellner \& Share, 2005; Luke, 1994) regarding decentering teacher power in the classroom and empowering students to construct their own knowledge. We also explore why someone might spread false information and our roles in spreading or preventing such fake information. This has the dangerous 
consequence of possibly giving students ideas of how to spread more fake news. This has not explicitly happened, but one student suggested a future assignment to be for students to create a fake news item and spread it on social media as a social experiment, like "NASA girl" mentioned earlier. Fortunately, other students rejected this idea as they felt it went against the values of the course, and instead, collectively, we decided to do an assignment within the classroom itself or in person with others outside the class, where someone brought one piece of real news, one of deceptive/fake news, and we all guessed which was real and which was fake. That way, the person presenting the news could immediately correct any misunderstandings before something fake went viral.

5. Being explicit about an overarching goal of striving towards social justice and better understanding in the world, rather than gaining a skill to argue better or detect lies. An understanding that there may be sinister underpinnings as part of larger systems of power in the world, but that we have agency as individuals and as a society to resist. I am unsure if I provided an assessment as evidence that students have developed this, and I hope to do so in future.

From my students' final reflections this semester, I have chosen some quotes. They were asked to blog about the three most important things they learned in the class, and what helped them learn the most.

Two students, Nermeen and Yasmine created a game in the class to encourage people not to judge others and to empathize, building on what we had been doing in the course. For Nermeen, this was her natural disposition:

To be honest, l've always tried to give people reasons for who they are and what they do; and tried to put myself in their shoes but never actually have been through the experience of having to take decisions on their behalf and think of their situations as if they were my own situation. (Nabil, 2018b)

For Yasmine, this was something she developed during the course:

I learnt not to be judgmental. Although this might seem strange since the course is about digital literacies, still we got to learn about understanding and tolerating different perspectives of various topics in life. (Abdelghany, 2018)

In Pansee's final reflection, she shows similar behavior to Belenky et al.'s (1986) findings about women feeling torn between believing and disbelieving, and then maturing to see the complexity and a degree of self-awareness of what makes her more likely to believe:
I've always been very skeptical of things I read online and almost never believe them; however, I tend to slightly start believing online news when they start spreading across social media and everyone is talking about them or when the content is being said by someone in a video. (Moussa, 2018)

Hanan, a journalism student, shared how the Fake It to Make It game (which puts the player in the position of someone intentionally creating fake news) helped her understand how this works as a process not just as something we consume:

I had never been put in a practical situation to deal with fake news or need to understand how the fake news business operates. The game called Fake It to Make It put this idea into perspective, showing the impact that this news has on us and the people around us. (Rashwan, 2018)

On the course's larger goal to nurture more empathetic critical citizens, Mahmoud Yehia's (2018) final reflection included this: "I have learned a lot about becoming more of a human integrated in the world society than anything else". In his blogpost, he describes how he took what he was learning in his class and talked to his family and friends about how to assess credibility of information they find on social media so that more of us are aware and fewer people share fake news.

Another student, Karim Habashi wrote:

Going into a class and discussing the topic decided by the doctor with the other students in the class made me learn that there is a way easier way of memorizing information then writing them down and reading them back and forth. I have also learned from this class that students...always have something to add to what the doctor has to say. Most of the time the additions that students have are what we end up [remembering]. This automatically lead me to learn that one often learns more while having a dialogue than by attending a lesson and taking notes. I noticed I was learning from dialogues. (Habashi, 2018)

Student final reflections overall show that students approached the topic of digital literacies from a dimension of empathy and understanding of the other, and through a contextual, reasonable doubting, rather than through antagonistic and exaggerated skepticism. Over several semesters, in their written and oral reflections, students have said they valued the in-class discussions and felt heard by the teacher and other students. While this can happen in classes without a feminist pedagogy, it is essential that feminist pedagogy provides such an environment, but the important dimension to keep working on is to ensure that dominant voices do not take over the discussions to the extent that they silence other voices, and that students for whom discussions result in confusion 
find a way to navigate these and distill their learning in order to transfer it to other contexts. At the end of such a course, one cannot know the depth of its impact on students, and if I had the opportunity to follow students a few years later, after graduation, to see how much of the course still remained with them, I would be interested to see if they changed their digital literacy practices, but also if they retained some of the values of empathy and social justice we explored in the course, especially if they majored in engineering or business where such topics are rarely, if ever, explored.

\section{Acknowledgments}

The author would like to acknowledge the influence of the following people on her thinking on this topic: Frances Bell, Kate Bowles, Catherine Cronin, Mia Zamora, Mike Caulfield, Renee Hobbs. The author would also like to express gratitude for the four peer reviewers whose constructive feedback was invaluable to her learning and helped vastly improve the quality and usefulness of this article by expanding her own knowledge and thinking.

\section{Conflict of Interests}

The author declares no conflict of interest.

\section{References}

Abdelghany, Y. (2018, December 15). Final reflection [Blog post]. Retrieved from https://yasmin abdelghanyblog.wordpress.com/2018/12/15/finalreflection

Association of College and Research Libraries. (2015). Framework for Information Literacy for Higher Education. Retrieved from http://www.ala.org/acrl/ standards/ilframework

Adichie, C. N. (2009). The danger of a single story. TED Talk. Retrieved from https://www.ted.com/talks/ chimamanda_adichie_the_danger_of_a_single_ story

Alexander, B., Adams Becker, S., Cummins, M., \& Hall Giesinger, C. (2017). Digital Literacy in Higher Education, Part II: An NMC Horizon Project Strategic Brief. Austin, TX: The New Media Consortium.

Andreotti, V. d., Stein, S., Ahenakew, C., \& Hunt, D. (2015). Mapping interpretations of decolonization in the context of higher education. Decolonization: Indigeneity, Education \& Society, 4(1), 21-40.

Asgharzadeh, A. (2008). The return of the subaltern: International education and politics of voice. Journal of Studies in International Education, 12(4), 334-363. https://doi.org/10.1177/1028315307308137

Bali, M. (2013). Critical thinking in context: Practice at an American liberal arts university in Egypt (Unpublished doctoral dissertation). University of Sheffield, Sheffield, UK. Retrieved from http://etheses.white rose.ac.uk/4646
Bali, M. (2014). Why doesn't this feel empowering? The challenges of web-based intercultural dialogue. Teaching in Higher Education, 19(2), 208-215. https://doi.org/10.1080/13562517.2014.867620

Bali, M. (2018, February 24). Skepticism and trust and a class activity [Blog post]. Retrieved from https:// blog.mahabali.me/educational-technology-2/ skepticism-trust-and-a-class-activity

Bali, M., Awwad, A., Halawa, F., Hassib, F., Khalifa, J., \& El Serogy, F. (2019). Global citizenship education in a digital age: (Re) Imagining subjects and citizens. In J. Dorio, E. Abdou, \& N. Moheyddin (Eds), The struggle for citizenship education in Egypt: (Re)lmagining subjects and citizens. New York and Oxon: Routledge.

Barnett, R. (1997). Higher education: A critical business. Buckingham: Society for Research into Higher Education and Open University Press.

Baxter Magolda, M. B. (2004). Evolution of a constructivist conceptualization of epistemological reflection. Educational Psychologist, 39(1), 31-42.

Belenky, M. F., Clinchy, B. M., Goldberger, N. R., \& Tarule, J. M. (1986). Women's ways of knowing: The development of self, voice, and mind (Vol. 15). New York, NY: Basic books.

Belshaw, D. (2016). The essential elements of digital literacies. Retrieved from https://dougbelshaw.com/ blog/2016/06/27/ebook-now-free

Benesch, S. (1999). Thinking critically, thinking dialogically. TESOL Quarterly, 33(3), 573-580. https://doi. org/10.2307/3587682

Benesch, S. (2001). Critical English for academic purposes: Theory, politics, and practice. Mahwah, NJ: L. Erlbaum Associates.

Brodin, E. (2007). Critical thinking in scholarship: Meanings, conditions and development (Unpublished doctoral dissertation). Lund University, Lund, Sweden.

Brookfield, S. D. (1987). Developing critical thinkers: Challenging adults to explore alternative ways of thinking and acting. San Francisco, CA: Jossey-Bass.

Burnett, C., \& Merchant, G. (2011). Is there a space for critical literacy in the context of social media? English Teaching: Practice and Critique, 10(1), 41-57. Retrieved from http://education.waikato.ac. nz/research/files/etpc/files/2011v10n1art3.pdf

Caulfield, M. A. (2017). Web literacy for student factcheckers. (n.p.): Michael A. Caulfield. Retrieved from https://webliteracy.pressbooks.com

Egypt Independent. (2018, October 25). Update: AUC student lied about NASA inviting her for 'giant BBQ'. Egypt Independent. Retrieved from https:// ww.egyptindependent.com/egyptian-tells-nasa-touse-a-giant-bbq-as-rocket-launch-pad-they-accept

El Rayess, M., Chebl, C., Mhanna, J., \& Hage, R., (2018) Fake news judgement: The case of undergraduate students at Notre Dame University-Louaize, Lebanon. Reference Services Review, 46(1), 146-149. https://doi.org/10.1108/RSR-07-2017-0027

Elbow, P. (1994). Teaching two kinds of thinking by teach- 
ing writing. In K. S. Walters (Ed.), Rethinking reason: New perspectives on critical thinking (pp. 25-32). Albany, NY: SUNY.

El-Sherbiny, H. (2018, December 4). Curation: Fake news [weblog post]. Retrieved from https://hana.travel. blog/2018/12/04/curation-fake-news

Facione, P. A. (1990). Critical thinking: A statement of expert consensus for purposes of educational assessment and instruction-Executive summary. The Delphi report. Milbrae, CA: The California Academic Press. Retrieved from http://www.insight assessment.com/pdf_files/DEXadobe.PDF

Fields, A. M. (2001). Women's epistemological development: Implications for undergraduate information literacy instruction. Research Strategies, 18(3), 227-238. https://doi.org/10.1016/S0734-3310(02)00089-7

Freire, P. (1970/1993). Pedagogy of the oppressed. 30th anniversary edition. New York and London: Continuum International.

Habashi, K. (2018, December 11). Final reflection [blog post]. Retrieved from https://karimhabashi.home. blog/2018/12/11/final-reflection

Hobbs, R. (2010). Digital and media literacy: A plan of action. Washington, DC: The Aspen Institute. Retrieved from https://mediaeducationlab.com/sites/default/ files/Hobbs\%2520Digital\%2520and\%2520Media\%25 20Literacy\%2520Plan\%2520of\%2520Action_0_0.pdf

Ito, M., Gutiérrez, K., Livingstone, S., Penuel, B., Rhodes, J., Salen, K., . . Watkins, C. (2013). Connected learning: An agenda for research and design. Irvine, CA: Digital Media and Learning Research Hub. Retrieved from https://dmlhub.net/wp-content/uploads/files/ Connected_Learning_report.pdf

Jenkins, H., \& Joll, (2014). How do digital media \& learning (DML) and media literacy communities connect? Why is it important that these communities work together towards common goals? Connections. Retrieved from http://www.medialit.org/readingroom/how-do-digital-media-learning-dml-andmedia-literacy-communities-connect-why-it

Johnson, L., \& Morris, P. (2010). Towards a framework for critical citizenship education. The Curriculum Journal, 21(1), 77-96. https://doi.org/10.1080/ 09585170903560444

Kellner, D., \& Share, J. (2005). Toward critical media literacy: Core concepts, debates, organizations, and policy. Discourse: Studies in the Cultural Politics of Education, 36(3), 369-386. https://doi.org/10.1080/ 01596300500200169
Moussa, P. (2018, December 15). Final reflection [Blog post]. Retrieved from https://panseemoussa. wordpress.com/2018/12/15/final-reflection

Nabil, N. (2018a). Fake news curation [Blog post]. Retrieved from https://nermeenahmednabil.word press.com/2018/11/25/fake-news-curation

Nabil, N. (2018b, December 15). Final reflection [Blog post]. Retrieved from https://nermeenahmednabil. wordpress.com/2018/12/15/final-reflection

Noble, S. U. (2018). Algorithms of oppression: How search engines reinforce racism. New York, NY: NYU Press.

Luke, C. (1994). Feminist pedagogy and critical media literacy. Journal of Communication Inquiry, 18(2), 30-47.

Pangrazio, L. (2016). Reconceptualizing critical digital literacy. Discourse: Studies in the Cultural Politics of Education, 37(2), 263-274. https://doi.org/10.1080/ 01596306.2014 .942836

McPeck, J. E. (1990). Teaching critical thinking: Dialogue and dialectic. New York, NY: Routledge.

Rashwan, H. (2018, December 15). Final reflection [Blog post]. Retrieved from https://hananrashwan. wordpress.com/2018/12/15/final-reflection

Rheingold, H. (2012). Net smart: How to thrive online. Cambridge, MA: MIT Press.

Takayama, K., Heimans, S., Amazan, R., \& Vegneskumar, M. (2016). Doing southern theory: Towards alternative knowledges and knowledge practices in/for education. Postcolonial Directions in Education, 5(1), 1-25. Retrieved from https://www.um.edu.mt/pde/ index.php/pde1/article/view/72/115

Teaching Tolerance. (2017). Digital literacy framework. Retrieved from https://www.tolerance.org/ frameworks/digital-literacy

Thayer-Bacon, B. (1998). Transcribing and redescribing critical thinking: Constructive thinking. Studies in Philosophy and Education, 17, 123-148.

Tufecki, Z. (2018, August 14). How social media took us from Tahrir Square to Donald Trump. MIT Technology Review. Retrieved from https://www. technologyreview.com/s/611806/how-social-mediatook-us-from-tahrir-square-to-donald-trump

Walters, K. S. (1994). Introduction: Beyond logicism in critical thinking. In K. S. Walters (Ed.), Re-thinking reason: New perspectives on critical thinking (pp. 1-22). Albany, NY: SUNY.

Yehia, M. (2018, December 17). Final reflection [Blog post]. Retrieved from https://mahmoudyehia.home. blog/2018/12/17/final-reflection

\section{About the Author}



Maha Bali is Associate Professor of Practice at the Center for Learning and Teaching at the American University in Cairo. She holds a PhD in Education from the University of Sheffield, UK. She is on editorial boards of several journals of higher education and educational technology. She is co-founder of virtuallyconnecting.org and co-facilitator of Equity Unbound. She is an advisory board member of Erasmus+ Virtual Exchange and OneHE. She is a learnaholic, writeaholic and passionate open and connected educator. 